УДК 343.71:340.13

DOI https://doi.org/10.32849/2663-5313/2019.6.46

\title{
Лілія Лісниченко,
}

науковий співробітник

Державного науково-дослідного інституту

Міністерства внутрішніх справ Украйни

\section{КРИМІНАЛЬНО-ПРАВОВА ХАРАКТЕРИСТИКА ГРАБЕЖІВ І РОЗБІЙНИХ НАПАДІВ}

У статті проаналізована кримінально-правова природа грабежів $і$ розбійних нападів як видів корисливо-насильницьких злочинів. Обгрунтовується важливість дослідження кримінально-правових ознак, притаманних зазначеним діянням, з метою вироблення ефективних форм протидї та засобів захисту інтересів людей, суспільства й держави від иих посягань. Визначаються як спільні ознаки ицх двох складів злочину, так і відмінні ознаки, за якими вони розмежовуються.

Ключові слова: злочинність, корисливо-насильницькі злочини, грабіж, розбій, заходи запобігання.

Постановка проблеми. Соціально-економічні умови, що склалися в державі, змушують владу здійснювати оновлення заходів спрямованих на стримування злочинності, з урахуванням наукових ідей, вітчизняного та зарубіжного досвіду. Злочинність - негативне, історично мінливе, складне соціальне явище, яке включає сукупність неоднорідних, різнопланових суспільно небезпечних діянь. Загальноприйнятим є виділення таких двох груп злочинів, як корисливі, які полягають у протиправному заволодінні чужим майном, і насильницькі, тобто вчинення протиправних посягань на життя і здоров'я особи. Окрему проміжну групу становлять корисливо-насильницькі злочини - вчинення насильницьких дій із корисливих мотивів як способу подолання опору власника та заволодіння його майном. Основними видами злочинів цієї групи є грабежі й розбої.

Високий ступінь суспільної небезпечності та поширеність цих видів злочинів зумовлюють необхідність проведення наукових досліджень, спрямованих на аналіз чинних норм щодо кримінальної відповідальності за їх учинення, визначення й обгрунтування пропозицій щодо їх удосконалення.

Еволюція вчинення корисливо-насильницьких злочинів позначилася на розвитку наукових пошуків ефективних заходів кримінально-правового впливу на злочинців, удосконаленні практики протидії цим видам злочинних проявів. У різні історичні періоди корисливо-насильницька злочинність сприймалася як серйозна загроза найвищим соціальним цінностям, що зумовлювало суспільний запит на вироблення дієвих форм протидії та засобів захисту інтересів людей, суспільства й держави від корисливих насильницьких злочинних посягань, зниження ризику стати жертвою цих злочинів. Утім динамічний розвиток суспільства, спрямування держави на обмеження корисливо-насильницьких злочинів зумовили зміни в злочинній практиці, що, у свою чергу, потребує кримінально-правових норм щодо відповідальності за їх учинення.

Дослідженням проблем удосконалення кримінально-правових засобів у боротьбі зі злочинністю приділяли увагу такі вчені, як В.М. Кудрявцев, Н.Ф. Кузнєцова, М.А. Гельфер, В.А. Лихачов, Н.А. Голованова, В.П. Єрьомін, М.А. Ігнатова, А.А. Малиновський, М.I. Хавронюк, І.Ю. Малькова, С.А. Бочкарьов, В.Н. Ємельянов, М.Й. Коржанський, В.О. Навроцький, Р.Л. Максимович, А.Е. Жалинский та ін. Проте ці питання розглядалися ними в контексті протидії злочинності загалом. Питання щодо вдосконалення кримінально-правових засобів і методів протидії безпосередньо грабежам і розбійним нападам досліджували Б.М. Головкін, В.В. Батиргареєва, С.В. Албул, О.М. Литвак, Д.В. Петров, В.В. Семенко, Н.Т. Алієв та інші.

Метою статті є дослідження кримінальноправової природи та міри суспільної небезпечності грабежів і розбійних нападів, суттєвих ознак цих складів злочину.

Виклад основного матеріалу. Грабіж, передбачений ст. 186 Кримінального кодексу України (далі - КК), і розбій, згідно зі ст. 187 КК, розташовано в розділі VI Ocoбливої частини КК «Злочини проти власності» [1]. У науці кримінального права прийнятим $€$ те, що назва розділу Особливої частини вказує на родовий об'єкт злочинів, які охоплюються відповідними статтями. Отже, всі злочини, визначені статтями розділу VI Особливої частини КК, посягають на власність. 
Грабіж - це заволодіння чужим майном відкритим способом, поєднаним із насильством, яке не є небезпечним для життя чи здоров'я особи, або погрозою застосуванням такого насильства. Посягає грабіж на врегульовані законом суспільні відносини власності, право власності на майно, тому безпосереднім об'єктом грабежу варто вважати сукупність суспільних відносин власності з приводу володіння, користування та розпорядження майном, а додатковим безпосереднім об'єктом - свободу й тілесну недоторканність особи.

Розбій належить до найбільш небезпечних корисливо-насильницьких злочинів. Він також посягає на два об'єкти: право власності й особу (ії здоров'я і життя). 3 об’єктивного боку розбій учиняється у формі нападу з метою заволодіння чужим майном, поєднаного з насильством, небезпечним для життя чи здоров'я особи, яка зазнала нападу, або 3 погрозою застосування такого насильства.

Характерною спільною ознакою цих злочинів є посягання на право власності. Знання про власність в теорії і практиці кримінального права $є$ сталим, вони формулюють іiї як не природну даність, а соціальний конструкт [2, с. 20]. Не викликає сумніву те, що власність породжена суспільством, а тому визнаєтьсятой факт,щородовими (дочірніми) для відносин власності є суспільні відносини.

Щодо права власності вченими наголошується, що шкода під час учинення грабежу або розбою завдається не праву власності на це майно, а саме майну, оскільки в результаті викрадення майна власник не втрачає права власності на нього й може в будь-який момент витребувати своє майно з будь-якого незаконного володіння, а винна особа ніколи не зможе здобути права власності на майно, яке перебуває в незаконному користуванні, оскільки, відповідно до цивільного законодавства, право власності виникає лише на законних підставах. Із цього приводу В.П. Смельянов зазначає: «Нерідко як контраргумент використовується теза про те, що при викраденні майна викраденій речі ніякої шкоди не заподіюється, тому майно не $є$ об'єктом злочину. Проте ця теза теж є не чим іншим, як результатом змішування понять. Дійсно, конкретній викраденій речі ніякого збитку не заподіюється і заподіяно бути не може, оскільки не для того ця річ викрадалася, щоб заподіяти їй шкоду, а для того, щоб отримати з цього якусь користь. Збиток заподіюється майну власника як сукупності майнових благ, як деякій майновій масі, наявному майновому фонду, що реально зменшується за рахунок викрадення тієї або іншої речі» [3, с. 135].
Викраденням варто вважати корисливе, протиправне й неоплатне заволодіння чужим майном або іншими предметами 3 метою звернення їх у свою власність [4, с. 230]. Серед ознак викрадення виокремлюють незаконність (поза волею власника) і безоплатність, яка полягає в тому, що винний не повертає викрадене, не оплачує його вартість, не відшкодовує їі будь-яким еквівалентом [5, с. 494]. В.О. Навроцький уважає, що протиправне, безоплатне вилучення майна 3 володіння суб'єктів права власності й звернення його на користь інших суб'єктів, учинене шляхом грабежу, розбою, - це розкрадання майна [6, с. 231].

Під час учинення грабежу та розбою відбувається викрадення рухомого майна. I для грабежу, і для розбою характерне відкрите його викрадення. Грабіж може вчинятися без застосування насильства та із застосуванням його, а розбій завжди вчиняється шляхом насильства. Різниця між складами полягає в ступені небезпечності насильства для життя і здоров'я особи.

У чинному КК зміст поняття «викрадення» не розкривається, хоча в ст. 186 КК визначено, якого саме діяння воно стосується, а саме «грабіж - це відкрите викрадення чужого майна». Крім того, у кримінальному законі щодо діяння «грабіж» поняття викрадення містить указівку водночас на діяння як ознаку об'єктивної сторони складу злочину й на суспільно небезпечний наслідок. У статті 187 КК «Розбій» для вказівки на діяння як ознаку об'єктивної сторони складу злочину законодавцем використано термін «заволодіння», при цьому не роз'яснено, що охоплюється цим поняттям.

У роботах учених висловлено позицію про тотожність поняття «викрадення» та «розкрадання». На думку В.Г. Кундеус, збіг за обсягом категорій «викрадення» й «розкрадання» відбувається в діяннях, кваліфікованих як грабіж і розбій (ст. ст. 186, 187 КК), оскільки викрадення майна водночас виступає і як видова категорія викрадення, і як видова категорія розкрадання. В інших випадках існує викрадення без розкрадання (наприклад, викрадення людини) й розкрадання без викрадення (наприклад, шахрайське заволодіння правом на майно). Ученим обгрунтовано, що викрадення здійснюється шляхом фізичного вилучення рухомого майна чи будь-яких інших речей із будь-яких мотивів, а розкрадання - шляхом обернення майна чи права на майно з корисливих спонукань на свою або інших осіб користь [7, с. 4-5]

Р.Л. Максимович не погоджується з думкою, що склади злочинів грабіж і розбій можуть бути вчинені з будь-яких моти- 
вів, оскільки в теорії кримінального права $є$ позиція, згідно із якою для цих та інших форм розкрадання характерним є корисливий мотив. Відсутність такого мотиву може бути підставою для іншої кримінально-правової оцінки відповідного суспільно небезпечного діяння (наприклад, за ст. 356 КК «Самоправство») [8, с. 250].

Предметом грабежу та розбою є майно, що характеризується трьома основними ознаками: 1) фізичною, тобто сукупністю речей матеріального світу, які можна вилучити, привласнити, спожити, пошкодити, знищити; 2) економічною, або вартісною, грошовою; 3) юридичною: право на майно належить його власникові, фізичній чи юридичній особі, а для злочинця воно завжди $є$ чужим [9, с. 155-156].

3 урахуванням способу вчинення, а також мотиву й мети злочини грабіж і розбій належать до однієї з традиційно визначених у кримінальному праві групи злочинів проти власності, розкрадання чужого майна, грошей, цінностей і характеризуються прямим умислом і корисливою метою.

Грабіж уважається закінченим злочином із моменту заволодіння майном. Таким моментом визнається поява в злочинця реальної початкової можливості розпорядитися вилученим майном (винести, передати іншим особам тощо). Якщо особа, котра протиправно заволоділа майном, такої реальної можливості не мала, іï дії варто розглядати як замах на грабіж.

Розбій визнається закінченим із моменту нападу, поєднаного із застосуванням або з погрозою застосування насильства, небезпечного для життя чи здоров'я, незалежно від того, чи заволоділа винна особа чужим майном. У роз'ясненнях Пленуму Верховного Суду України зазначено, якщо особа, котра протиправно заволоділа майном, такої реальної можливості не мала, іiї дії варто розглядати залежно від обставин справи як закінчений чи незакінчений замах на вчинення відповідного злочину [10].

Суб'єктом грабежу й розбою може бути лише фізична осудна особа, яка досягла 14 років (громадянин України, іноземець або особа без громадянства).

На окрему увагу заслуговує насильницький спосіб поведінки суб'єктів насильницького грабежу та розбою, що є спільною рисою зазначених діянь. У роботах багатьох учених висловлюються думка, що саме насильницький спосіб поведінки, а не найпоширеніше спонукання людської діяльності до отримання незаконної вигоди варто визнати характерною особливістю грабежів і розбоїв [11-17]. Термін «насильство» не закрі- плено кримінально-правовими нормами, а в науковій літературі насильство визначають як дію або бездіяльність однієї людини стосовно іншої, що завдає шкоди здоров'ю, як фізичному, так і психічному, принижує почуття честі й гідності. Типологія насилля виокремлює «фізичне», «психічне», «економічне» насилля. Під фізичним насильством розглядають навмисне заподіяння побоїв, тілесних ушкоджень, яке може призвести чи призвело до порушення нормального стану фізичного чи психічного здоров'я або навіть смерті постраждалого, а також приниження його честі й гідності. Психологічне насильство характеризують як пов'язане 3 тиском однієї людини на психіку іншої через навмисні словесні образи або погрози, переслідування, залякування, які доводять постраждалого до стану емоційної невпевненості, втрати здатності захистити себе й можуть заподіяти або заподіяли шкоду психічному здоров'ю. Економічне насильство називають навмисні дії, спрямовані на те, щоб позбавити постраждалого житла, їжі, одягу та іншого майна чи коштів, на які він має законне право. Такі дії можуть заподіяти шкоду фізичному чи психічному здоров’ю або навіть призвести до смерті постраждалого [18]. У більшості випадків грабежу метою застосування насильства $є$ вилучення майна. При цьому застосування насильства передує його вилученню. Але насильство може бути застосоване й із метою утримання вже вилученого майна й у цьому разі застосовуватися після його вилучення. Від грабежу, поєднаного $з$ насильством, варто відрізняти так званий грабіж-ривок, за якого винний застосовує певні зусилля, щоб вирвати в потерпілого майно. У цьому випадку кваліфікація повинна бути лише за ч. 1 ст. 186 КК.

\section{Висновки}

Підсумовуючи й узагальнюючи досліджений матеріал, зазначимо, питання протидії злочинності ніколи не втрачало своєї актуальності, зокрема, в умовах економічного спаду та посилення соціального напруження в суспільстві. Важливість дослідження кримінально-правової природи та виокремлення ознак, притаманних грабежам і розбійним нападам, впливає на вироблення ефективних форм протидії та дієвих механізмів захисту інтересів людей, суспільства й держави від корисливих насильницьких злочинних посягань.

У кримінально-правовій теорії грабежі й розбійні напади зараховують до корисливонасильницьких злочинних діянь, які мають низку схожих ознак.

По-перше, зазначені діяння характеризують як двооб'єктні, при цьому висловлюва- 
лися різні судження стосовно пріоритетності охорони сфери суспільних відносин, якій першочергово заподіюється шкода. Під час учинення насильницьких грабежів, а також розбоїв водночас порушуються кримінально-правові заборони в декількох суміжних сферах охорони суспільних відносин: власності, свободи й тілесної недоторканності особи в першому випадку та власності, життя і здоров'я потерпілих у другому випадку.

По-друге, спільною для цих видів злочинів $є$ наявність корисливого мотиву й цілі заволодіти майном, що перебуває у власності, натомість розбій виділяють як особливо небезпечний спосіб заволодіння майном інших осіб. I єдиним чинником, який відрізняє ці два суміжні склади злочинів, є саме ознака небезпечності насильства для життя i здоров'я потерпілого. На однорідність грабежів і розбоїв указує й спільний предмет злочинних посягань, а саме чуже майно.

До ознак, за якими розрізняються ці злочини, належать:

- насильство є типовою характеристикою грабежів і розбоїв, які через це традиційно називають корисливо-насильницькими злочинами. Характер фізичного та психічного насильства (під час грабежу для досягнення своєї мети винний застосовує насильство, що не є небезпечним для життя або здоров'я потерпілого, або погрозу такого насильства, під час розбою - насильство, завжди небезпечне для життя чи здоров'я особи, яка зазнала нападу, або погроза такого насильства);

- момент закінчення (грабіж за своєю конструкцією є злочином із матеріальним складом і вважається закінченим із моменту, коли винна особа вилучила майно й має реальну можливість розпоряджатися чи користуватися ним (із моменту заволодіння майном), розбій - усічений склад злочину, який уважається закінченим із моменту нападу, поєднаного із застосуванням або з погрозою застосування насильства, небезпечного для життя чи здоров'я, незалежно від того, чи заволоділа винна особа чужим майном.

Проведений аналіз дає підстави стверджувати, що викрадення для діянь грабіж і розбій є окресленим поняттям, яке неоднаково тлумачиться законодавцем, доктриною і правозастосовною практикою. Уважаємо, що під викраденням варто розуміти таємне чи відкрите протиправне, безоплатне вилучення майна 3 володіння суб'єктів права власності й звернення його на користь інших суб'єктів.

\section{Список використаних джерел:}

1. Кримінальний кодекс України: Закон України від 5 квітня 2001 року № 2341-III. База даних «Законодавство України» / ВР України.
URL: https://zakon.rada.gov.ua/laws/show/ 2341-14 (дата звернення: 28.05.2019).

2. Бочкарёв С.А. Собственность в уголовном праве / под ред. А.Э. Жалинского. Москва: Nota Bene, 2011.216 c.

3. Ємельянов В.П. Визначення об'єкта злочину в кримінально-правовій науці: дискусійні питання. Вісник Запоріз. юрид. ін-ту ДДУВС. 2009. № 2. С. 125-135.

4. Коржанський М.Й. Кваліфікація злочинів: навчальний посібник. Київ: Атіка, 2002. 640 с.

5. Кримінальний кодекс України: Науковопрактичний коментар / Ю.В. Баулін та ін.; за заг. ред. В.В. Сташиса, В.Я. Тація. 3-є вид., переробл. та доповн. Харків: Одіссей, 2006. 1184 с.

6. Навроцький В.О. Кримінальне право України. Особлива частина: курс лекцій. Київ: Знання, 2000. $771 \mathrm{c}$.

7. Кундеус В.Г. Кримінально-правова характеристика викрадення: автореф. дис. ... канд. юрид. наук: спец. 12.00.08. Харків, 2004. 19 с.

8. Максимович Р.Л. Викрадення як наскрізне кримінально-правове поняття. Науковий вісник Львівського державного університету внутрішніх справ. 2015. № 2. С. 247-255

9. Кримінальне право України: Особлива частина: підручник / Ю.В. Баулін та ін.; за ред. В.В. Сташиса, В.Я. Тація. Київ: Юрінком Інтер, 2007. $624 \mathrm{c}$.

10. Про судову практику у справах про злочини проти власності: Постанова Пленуму Верховного Суду від 06.11.2009 № 10. База даних «Законодавство Украӥни» / ВP України. URL: https://zakon.rada.gov.ua/laws/show/v0010700-09 (дата звернення: 28.01.2019).

11. Абельцев С.Н. Личность преступника и проблемы криминального насилия. Москва: ЮНИТИ-ДАНА, Закон и право, 2000. 207 с.

12. Гаухман Л.Д. Насилие как средство совершения преступления. Москва: Юрид. лит., $1974.167 \mathrm{c}$.

13. Курс кримінології: Особлива частина: підручник: у 2 кн. / за заг. ред. О.М. Джужі. Київ: Юрінком Інтер, 2001. Кн. 2. 480 c.

14. Жалинский А.Э. Насильственная преступность и уголовная политика. Сов. государство $u$ право. 1991. № 3. С. 101-112.

15. Закалюк А.П. Курс сучасної української кримінології: теорія і практика: у 3 кн. Київ: Ін Юре, 2007. Кн. 2: Кримінологічна характеристика та запобігання вчиненню окремих видів злочинів. $712 \mathrm{c.}$

16. Зелінський А.Ф. Кримінологія: навч. посіб. Харків: Рубікон, 2000. 240 c.

17. Головкін Б.М. Корисливо-насильницька злочинність в Україні: феномен, детермінація запобігання: монографія. Харків:Право, 2011.432 с

18. Царевська Ю. Насильство: короткий інструктаж для консультантів та консультанток Київ: МБФ «Альянс громадського здоров'я», 2017. URL: http://aph.org.ua/wp-content/ uploads/2017/06/Violance-booklet-press.pdf (дата звернення: 01.05.2019). 
В статье проанализирована уголовно-правовая природа грабежей и разбойньх нападений как видов корыстно-насильственных преступлений. Обосновывается важность исследования уголовноправовых признаков, присущих указанным действием, с иелью выработки эффективных форм противодействия и средств защиты интересов людей, общества и государства от этих посягательств. Определяются как общие признаки этих двух составов преступления, так и отличительнье признаки, по которым они разграничиваются.

Ключевые слова: преступность, корыстно-насильственные преступления, грабеж, разбой, меры предупреждения.

The article analyzes the criminal law nature of robberies and assaults with an intent to rob as types of acquisitive and violent crimes. It justifies the importance of studying the criminal law signs inherent in this action, with the aim of developing effective forms of counteraction and means of protecting the interests of people, society and the state from these attacks. The work identifies both the common features of these two elements of a crime and the distinguishing features by which they are differentiated.

Key words: crime, acquisitive and violent crimes, robberies, assaults with an intent to rob, preventive measures. 